Department of Anatomy (Prof. S. FuSE), Niigata University School of Medicine,

Niigata and Department of Anatomy and Embryology, Tokyo

Metropolitan Institute for Neurosciences, Fuchu,

Tokyo, Japan

\title{
Some Electron Microscope Findings of the Claustrum of the Cat
}

\author{
Masao Norita and Yukio Hirata
}

Received December 4, 1975

\begin{abstract}
Summary. The claustrum of the cat is basically composed of 4 classes of neuron. Class $I$ is a rather small neuron $(<10 \mu$ in diameter $)$ and is provided with rather few cytoplasmic organelles, while Class IV, large $(25-30 \mu)$, neuron possesses an abundance of them. Class II, medium-sized $(15-20 \mu)$, neuron and fusiform Class III neuron (about $15 \times 25 \mu)$ exhibit an intermediate form of the former two classes. Perikaryal and proximal dendritic surface of Class IV neurons are covered with many boutons, while neurons of the other three classes have few of such terminals on their perikaryal surface. The dendritic profiles of rather reduced diameter bear a few axonal terminals.

Five types of terminals are recognized: (1) Type A terminal, small in profile, with uniform sized round vesicles (about $300 \mathrm{~A}$ in diameter) making asymmetrical synapses; (2) Type $B$ terminal of small size, containing round vesicles of various diameters $(300-400 \AA)$ and forming asymmetrical synaptic contacts; (3) Type C, also small in profile, being filled with pleomorphic vesicles and making symmetrical synapses; (4) Type D large terminal with numerous pleomorphic vesicles, many mitochondria and a number of glycogen-like granules, forming symmetrical synapses; and (5) Type $\mathrm{E}$ terminal containing numerous granular vesicles $(800-1,000 \AA)$. The Type $C$ and some of Type A terminals usually synapse upon the cell bodies and proximal dendrites, while most of Type A, B, D and E make synapse upon medium to small dendritic profiles and spines.

The problem whether or not the cy toarchitecture of the claustrum at the light microscope level is identifiable at the ultrastructural level as well, and the possible origin of various types of terminals above described, were discussed briefly.
\end{abstract}

Many papers have been published concerning the developmental, architectural, hodological and electro-physiological aspects of the claustrum.

Earlier controversial opinions regarding the development of this grey matter were reviewed by AriËns KAPPERs, Huber and Crosby (1936). Ernst de VRIEs (1910) felt that the claustrum was part of the neopallium, drawn out subcortically to extend beneath the rhinencephalic sulcus, Rose (1928) considered that the claustrum was a derivative of the insular cortex. Filimonoff (1966), however, suggested that it could not be regarded as a derivative of the cortical plate or as a formation genetically similar to the striatum; it could be regarded only as an intermediate formation between these main types of the telencephalic structures. Up to date, however, no agreement has been reached among the investigators as to the ontogeny of the claustrum, and much controversy still exists.

The topography and the structure of this grey matter have been described by Whit aker (1921), Gurdian (1928), Rose (1928), Brockhaus (1938, 1940), Rae (1954), NARKiewicz (1964), Druga (1966a, 1974) and Miodoński (1975). The claustrum has been divided into a compact dorsal part, situated between the putamen and insular cortex, and a ventral portion, which extends as scattered cells toward the amygdala. WHITAKER (1921) found macroscopic continuity between the claustrum and amygda- 
loid complex. Druga (1966a) concluded that the dorsal claustrum of the cat was divided into the basic structure and three marginal zones (medial, dorsal and lateral) by the density and types of cells, and that the claustral neurons were classified into five types (large multipolar, large pyramidal, small multipolar, round and spindle cells) by using Nissl's and Golgi-Bubenaite methods. Recently the ultrastructural study of the claustrum of the cat was made by Juraniec, Narkiewicz and Wrzolkowa (1971), but they did not discuss whether or not the architecture of the light microscope level could be identified at the ultrastructural level.

Carman, Cowan and Powell (1964), Druga (1966b, 1968, 1971, 1972) and NArkiewicz $(1964,1966)$ reported that the claustrum was connected with almost all regions of the cerebral cortex. Nauta and Whitlock (1954) and Andersen (1968) suggested that the claustrum also received afferent fibers from a few subcortical structures. The claustrum is, however, difficult to destroy without involving its neighboring structures owing to its above mentioned anatomical topography. This situation, therefore, has restricted the attention of many works on the connections of this structure to its afferent one. NAUTA and WHITLOCK (1954) after injuring the nuclei centralis medius, submedius and reuniens of the cat, could trace degeneration into the claustrum. Carman, Cowan and Powell (1964) reported that the dorsal claustrum of the rabbit received projections from all areas of the neocortex and had a well-defined topographic organization. DRUGA (1971) noted that the ventral claustrum of the cat received afferent fibers from the paleocortex (prepyriform cortex). JuRANIEC, NARKIEwICZ and Wrzokkow A (1971) found that the cortico-claustral connections of the cat were mostly, if not exclusively, axo-dendritic and of the asymmetrical type, and that they were very numerous and diffusely distributed in the appropriate region of the claustrum. In the various descriptions of the claustral connections, however, little is known of the interrelations between claustral neurons and the different kinds of nerve terminals.

Although many electro-physiological studies of the claustrum have also been reported (Spector, 1969; Spector, Hassmannova and Albe-Fessard, 1970, 1974), no conclusive results have been obtained.

Consequently the following problems are the main object of the present investigation: whether or not (1) the architecture of the light microscope level is identifiable at the ultrastructural level, and (2) the past hodological results and some of their functional implications could be explained by the ultrastructural analysis.

Present morphological data provide the necessary background for ongoing experimental studies on the connections of this grey matter in the cat.

\section{Materials and Methods}

Normal adult cats, weighing $2.5-3.3 \mathrm{~kg}$ were anesthetized intraperitoneally with pentobarbital sodium. The brains were fixed by perfusion through the left cardiac ventricle with Ringer's solution followed by the aldehyde fixative ( $\mathrm{pH} 7.2-7.3$ ) containing $1 \%$ glutaraldehyde, $3.5 \%$ formaldehyde, and $2 \%$ sucrose, in 320 mOsM-phosphate buffer solution (KARLsson and Schultz, 1965). Thin slices which include the claustrum were cut in the coronal plane and then trimmed. The tissue blocks were rinsed briefly in the buffer solution containing $4 \%$ sucrose, and then postfixed for 2 hrs in a phosphate-buffer $1.3 \%$ osmium tetroxide solution, containing $2.7 \%$ sucrose. 
After dehydration by ethanol, tissue blocks were embedded in Epon 812 (LuFt, 1961). Ultrathin sections were mounted on formvar-coated copper grids, and were stained with uranyl acetate and lead citrate (VENABLE and Coggeshall, 1965). Sections were examined with a Hitachi HS-7S or JEOL 100B electron microscope. Thicker sections $(1.5-2.0 \mu)$ for light microscopy were also cut from the same blocks and were stained with toluidine blue.

\section{Results}

\section{Light Microscopic Observations}

The claustrum is divided into dorsal and ventral portions as descrived previously (Whitaker, 1921; Gurdjian, 1928; Rose, 1928; Narkiewicz, 1964; Druga, 1966a, 1974; Miodonski, 1975). The dorsal claustrum lies between the putamen and the cerebral cortex dorsal to the rhinal fissure, but it is distinguished clearly from both structures. The ventral claustrum is covered by the paleocortex, from which it is separated vague1y. Between the dorsal and ventral parts, the intermediate area is found, in which fusiform neurons are predominant.

The claustral neurons are various in form (round, triangular, polygonal and fusiform) and size, and can be sorted into 4 types; large, fusiform, medium and small neurons. The large neurons (Fig. 1a) are met only infrequently in the claustrum. Fusiform neurons (Fig. 1b) are mainly found in the peripheral and intermediate areas of the claustrum. In the other portions, however, medium-sized neurons (Fig. 1a) predominate. Small neurons (Fig. 1a) mostly of round shape, can be diffusely seen all over the claustrum.

All claustral neurons except small ones have a rather light nucleus while those of small neurons are rather dark. The nuclei of the large, medium, and small neurons are usually round (sometimes oval), while the fusiform neurons have the fusiform shape. The nuclei of large neurons have a relatively smooth contour but those of the remaining claustral neurons show marked nuclear indentations. The nuclear indentations are also found in neurons of the overlying cerebral cortex but can not be seen
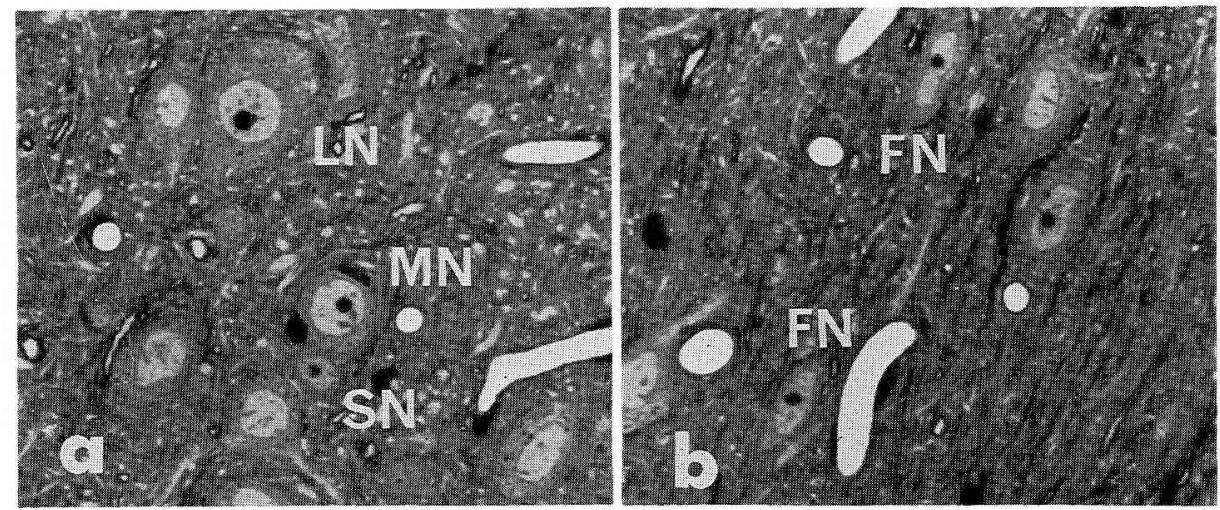

Fig. 1. Light micrographs of parts of cat claustrum. Toludine blue stained Epon sections. $\times 900$ a. Dorsal claustrum. Large $(L N)$, medium $(M N)$ and small $(S N)$ neurons are present. Note marked nuclear indentations in the latter two types of neurons. b. Intermediate area. Fusiform $(F N)$ neurons are predominant. 


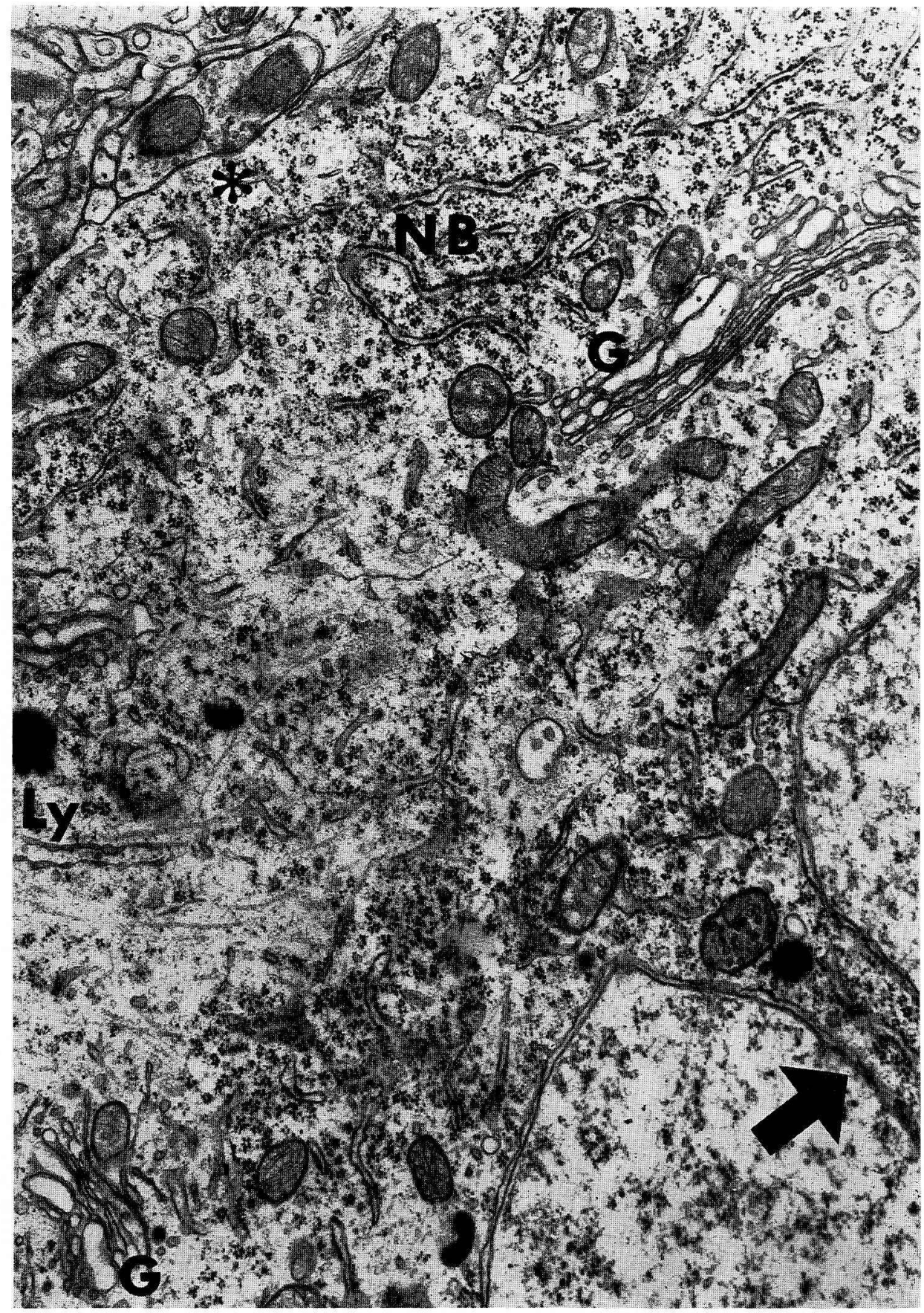

Fig. 2. Class II (medium) neuron possessing a deep invagination of the nuclear envelope (arrow) and poorly organized Nissl bodies $(N B)$ composed of several strands of randomly oriented rough endoplasmic reticulum. The somatic surface bears a synapse (asterisk). $L y$ lysosome, G Golgi apparatus. $\times 29,300$ 


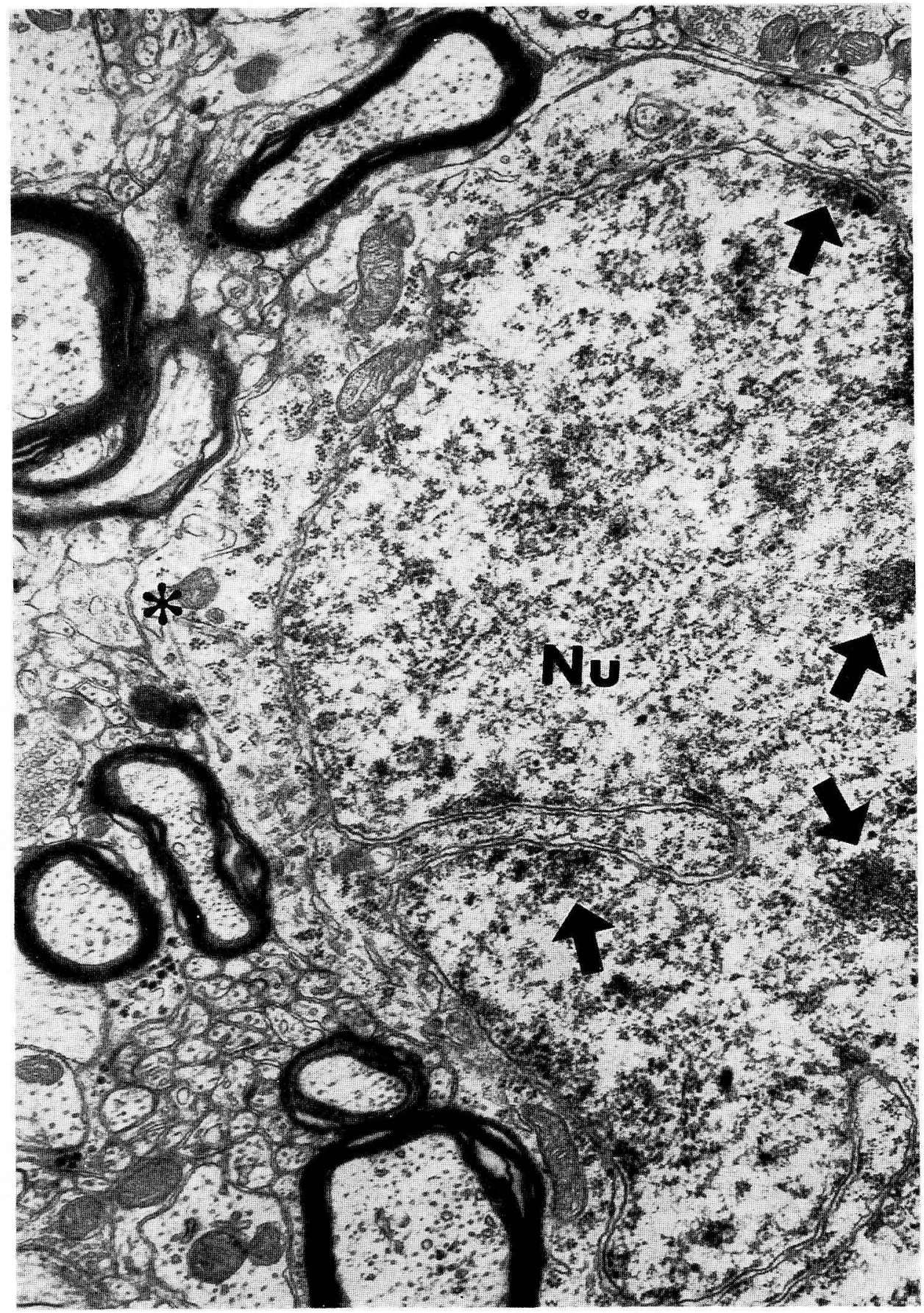

Fig. 3. Class I (small) neuron. The soma of small neuron is mainly occupied by the nucleus $(N u)$ which displays several chromatin aggregates (arrows). The cytoplasm is confined to a thin shell. Note the axo-somatic synapse (asterisk). $\times 29,300$ 
in the small neurons of the putamen.

In the cytoplasm of large, medium-sized and fusiform neurons, coarse granules of Nissl substance may be observed, while that of a small neuron contains very fine Nissl granules. Some, more darkly stained granules are present in the cytoplasm of most of the claustral neurons.

Myelinated fibers of various diameters are sparse in the claustrum; most of them are fine measuring less than $1 \mu$ in diameter. The glial cells and capillaries are of the same appearance as in other parts of the central nervous system.

\section{Electron Microscopic Observations}

\section{A. Nerve cells}

As the neurons in the claustrum in their general cytology resemble that of other neurons, the following description will emphasize only those features that seem to be peculiar to this grey matter or that have not been described before. Four classes of neurons can be identified by electron microscopy.

1) Class I (Fig. 3). These are rather small neurons $(<10 \mu)$. The nucleus of this class ordinarily appears rather dark compared to those of other classes of neurons. It is round or elliptic in shape with marked indentations, and is usually large in size in proportion to the cross-sectional area of the cell body. The narrow cytoplasm contains a few mitochondria and a few pairs of Golgi complexes; ribosomes are mostly free, only a small proportion being associated with the endoplasmic reticulum. A few microtubules and lysosomes ( $0.4 \mu$ in average diameter) are also present, the latter presumably corresponding to dark granules observed under the light microscope. These electron microscopic features suggest that this class corresponds to the "small neuron" identified in the light microscopy.

2) Class II (Fig. 2). This class represents the predominant neurons in the claustrum. They are round, triangular or polygonal in shape and measure $15-20 \mu$ in diameter. The nucleus is lighter in appearance than but similar in other respects to that of Class I. The endoplasmic reticulum is of lamellar or reticular form and other cell organelles are more developed in more abundant cytoplasm than Class I neurons. The cisterns of the endoplasmic reticulum are sometimes disposed in parallel array,
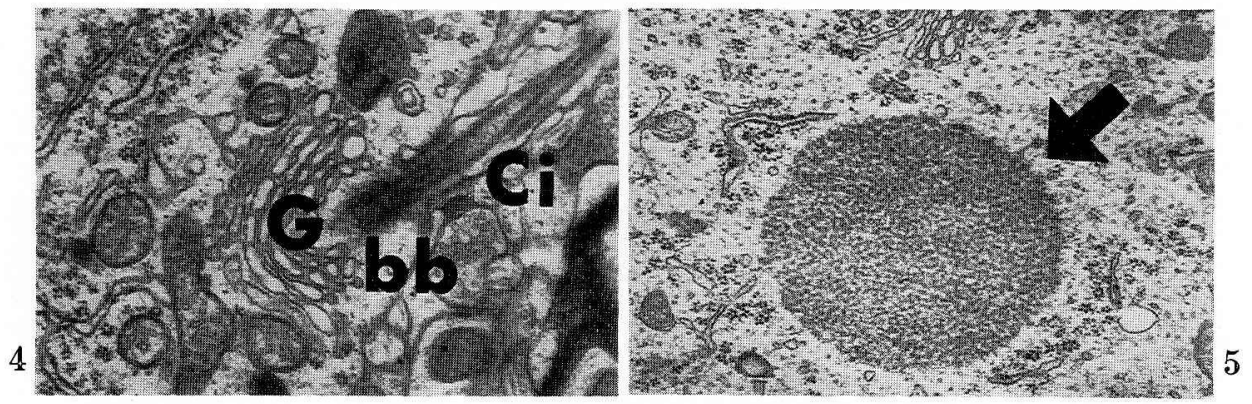

Fig. 4. A longitudinal section of a cilium $(C i)$ arising from a neuron. At the base of the cilium is a basal body $(b b)$ which is associated with the Golgi apparatus $(G) . \quad \times 20,000$

Fig. 5. The nucleolus-like body (arrow) in the cytoplasm of a Class II neuron. Note that this body has no limiting membrane. $\times 20,000$ 


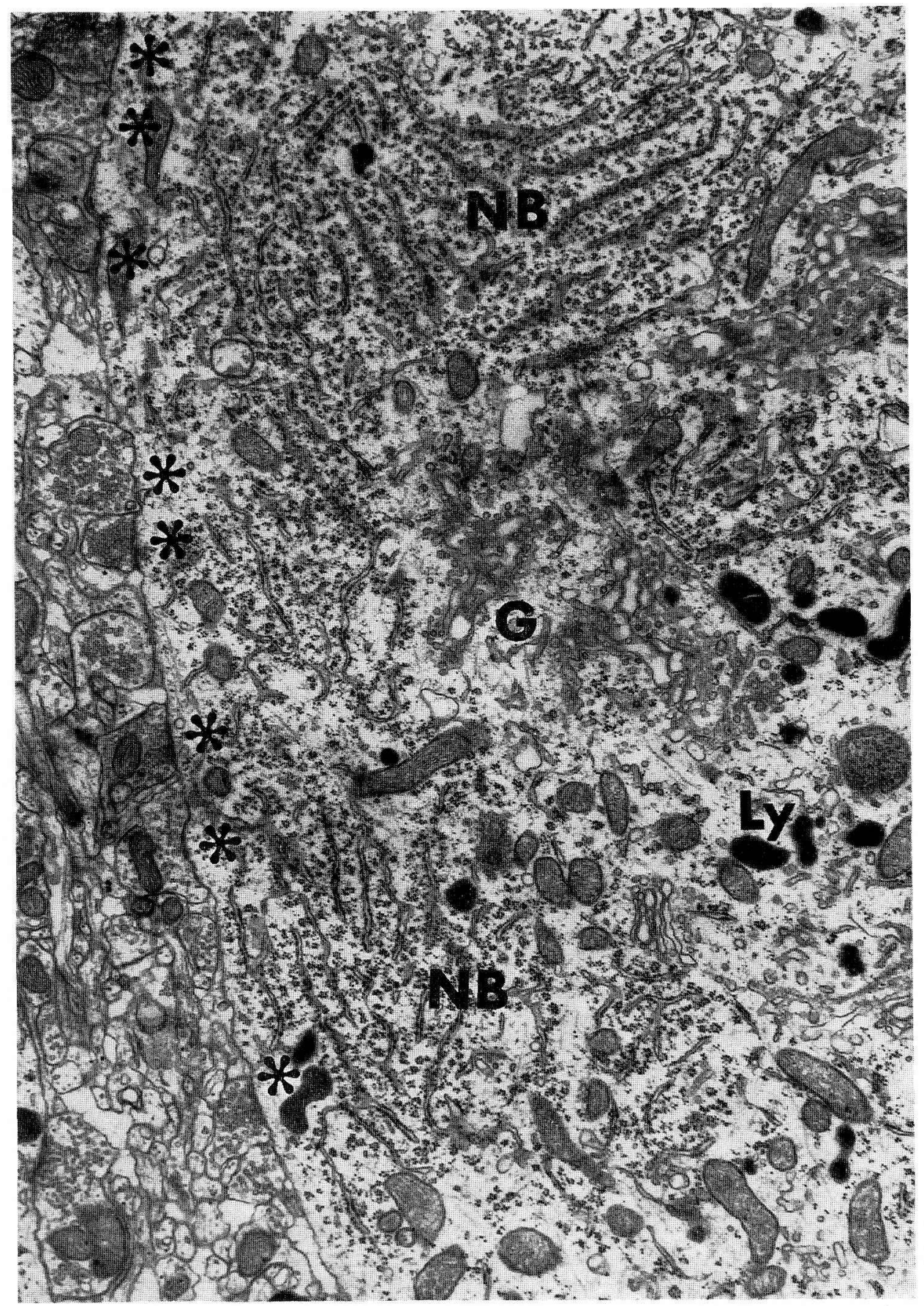

Fig. 6. Class IV (large) neuron. The cytoplasm is abundant, and Nissl bodies (NB) and other cytoplasmic organelles are well developed. Note that numerous axon terminals synapse upon the surface of this neuron (asterisks). $L y$ lysosome, $G$ Golgi apparatus. $\quad \times 16,000$ 


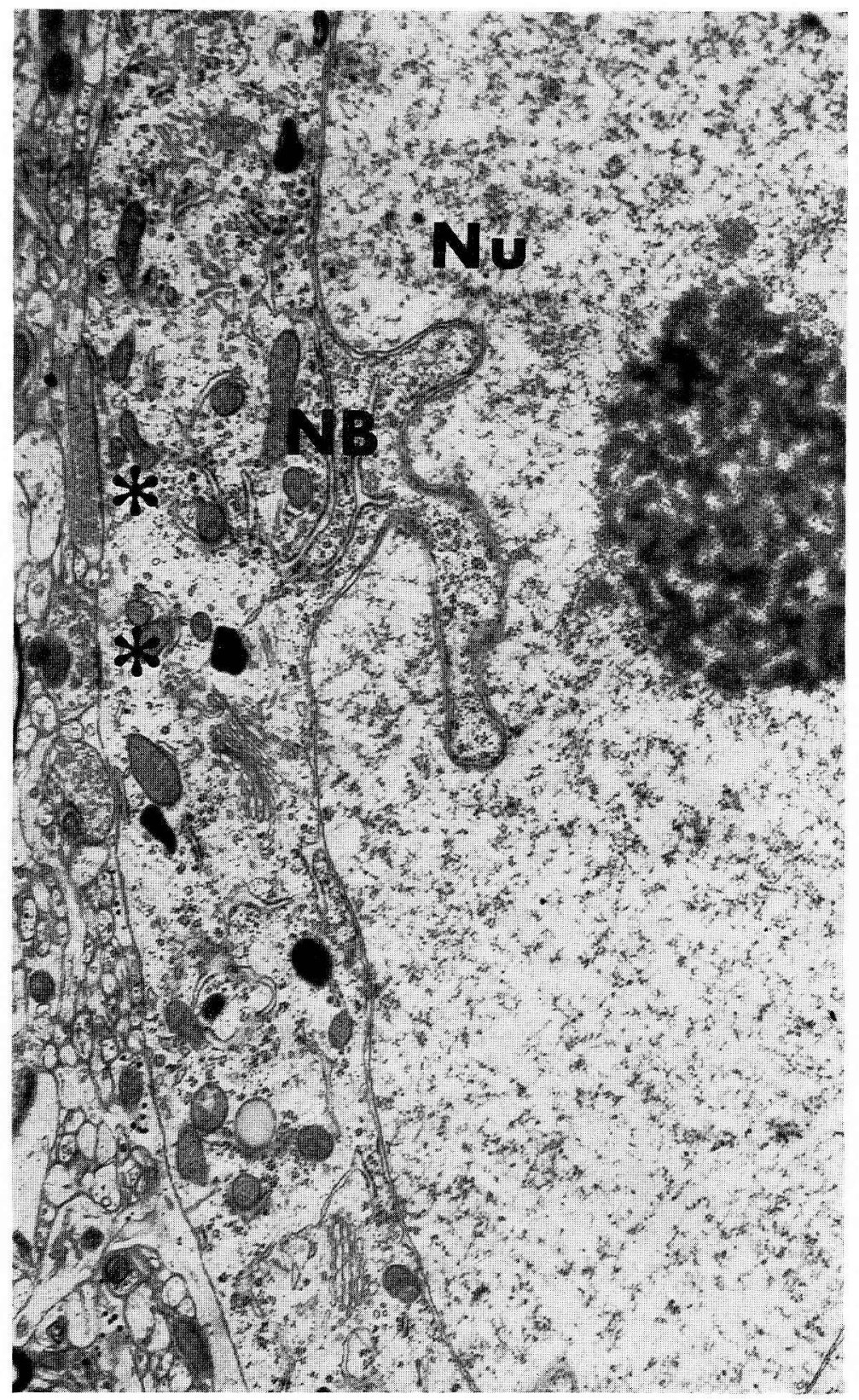

Fig. 7. Class III (fusiform) neuron. This neuron has an invaginated nucleus $(\mathrm{Nu})$, and the perikaryon possesses poorly organized Nissl bodies $(N B)$ and other cytoplasmic organelles. The soma bears two synapses (asterisks). $\times 18,200$ 
forming the Nissl substance. Occasionally, nucleolus-like bodies (maximum diameter $0.5-1.5 \mu$, average $1 \mu$ of roughly round form) are found in the cytoplasm. They are considerably high in electron density and consist of fine granules $(60-150 \mathrm{~A}$ in diameter), having no limiting membranes (Fig. 5). This type of body has been described in other parts of the central nervous system by LE BEUx (1971), KISHI (1972) and others. A cilium is sometimes seen to arise from this class of neuron (Fig. 4).

3) Class III (Fig. 7). Neurons of this class are characterized by their elongated (about $15 \times 25 \mu$ ) perikaryal contour. In other respects they are quite similar to Class II neurons. The "medium-sized neuron" and "fusiform neuron" in light microscopy

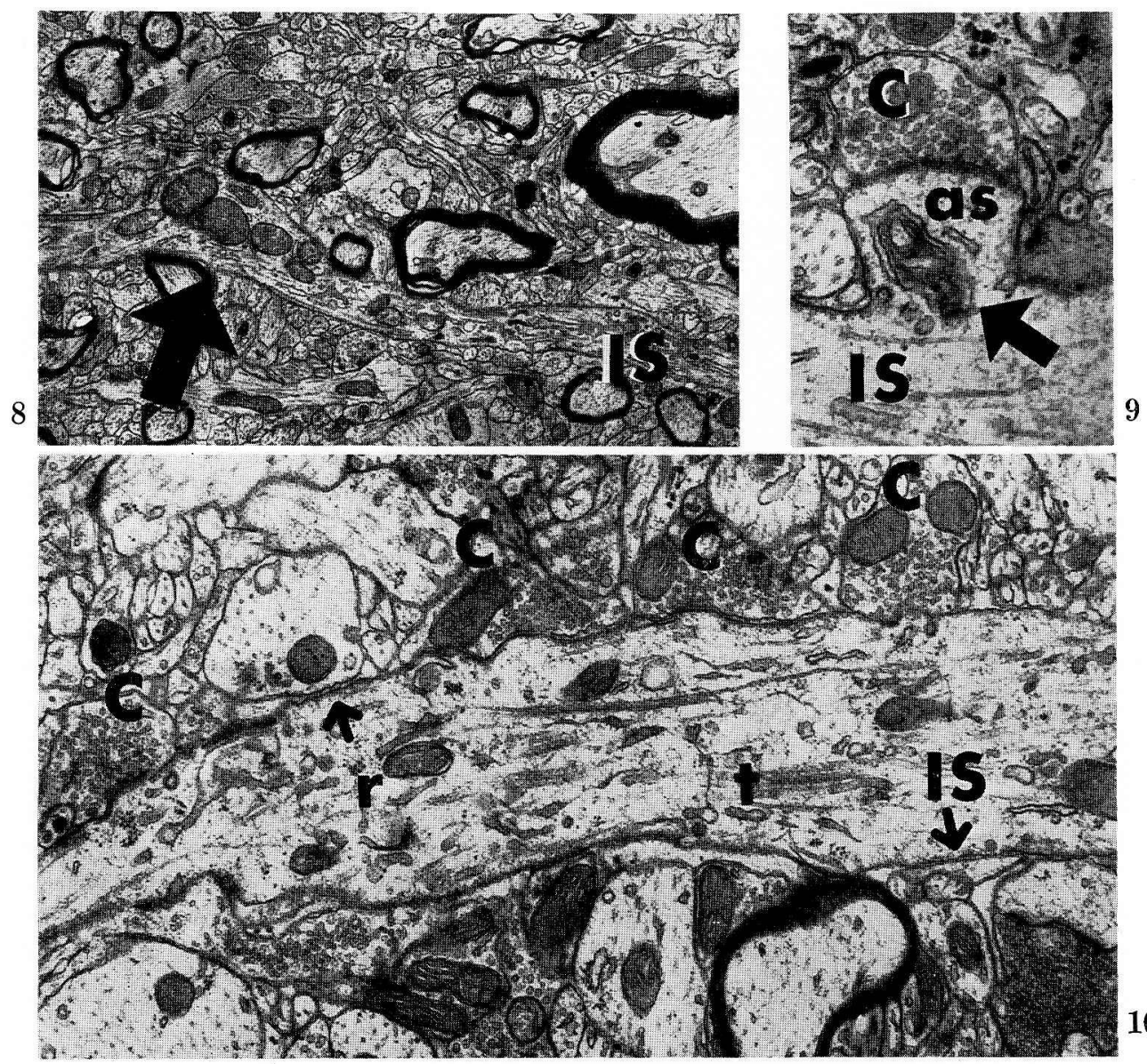

Fig. 8. The initial segment (IS) of the Class II neuron. Note its bulged portion (arrow) containing mitochondria. $\times 8,000$

Fig. 9. The initial segment (IS) with an axonic spine (as) which is contacted by a presynaptic process $(C)$ containing pleomorphic vesicles. A spine apparatus-like structure (arrow) is located near the synaptic contact. $\times 30,000$

Fig. 10. The initial segment (IS) longitudinaly sectioned. Note the electron-dense undercoating (arrows), fasicles of microtubules $(t)$, ribosomes $(r)$, receiving axon terminals $(C)$ which contain pleomorphic vesicles. $\times 20,000$ 
correspond to class II and III neurons, respectively.

4) Class IV (Fig. 6). The neurons of this class are large $(25-30 \mu)$ and found only infrequently in the claustrum. The nucleus usually lacks the marked indentations which characterized those of neurons belonging to other classes. The cytoplasm is the most abundant among the four classes of claustral neurons and has welldeveloped cell organelles in it. The perikaryal surface of this class of neuron bears many synaptic terminals which are few, if any, on other classes of neurons. This class corresponds to the "large neuron" in light microscopy.

\section{B. Initial segment}

Most of the initial segments, ranging from 0.8 to $1.6 \mu$ in diameter, originate from the cell body but a few emerge from the proximal dentrite. Its morphological characteristics are similar to those previously described in various regions of the central nervous system (Palay, Sotelo, Peters and Orkand, 1968; Peters, Palay and WEBster, 1970), although so-called initial segment spines (WEstrum, 1970) are sometimes found (Fig. 9). Most of the profiles identified as initial segments have one or more synaptic contacts (Fig. 10), although it has not been possible to obtain a complete initial segment continuous from the axon hillock to the myelinated portion. Some of the initial segments exhibit a few bulges in their course (Fig. 8), which usually contain some mitochondria.

\section{Synaptic organizations}

The synaptic terminals in the claustrum are generally small (about $1 \mu$ in diameter), even the biggest ones not exceeding $3 \mu$. Most of them make synaptic contacts against rather thin dendrites (less than $3 \mu$ in diameter) or spines. Synaptic junctions against axon, soma and proximal dendrite are less common. Most ultrastructural features of synapses in the claustrum are similar to those described in other areas of the mammalian nervous system (Palay, 1958; Peters and Palay, 1966). The classification of the synapses as asymmetrical or symmetrical is made according to Colonnier (1968).

At least five types of vesicle-containing terminal profiles can be identified by the size and shape of vesicles, type of contact, number of mitochondria and the presence of other organelles.

1) Type A terminal, found most commonly, is represented by a small profile with round vesicles of almost uniform diameter (about $300 \AA$ in diameter) and few mitochondria (Fig. 13). This type of terminal makes asymmetrical synaptic contact with either dendrite or spine. Besides, about four-fifths of the terminals synapsing on the soma of Class IV neuron belong to this type (Fig. 6).

2) Type B terminal, shows a small profile containing round vesicles of various diameters (300-400 $\AA$ ) and a few mitochondria (Fig. 13). This terminal makes asymmetrical synaptic contact upon small dendritic profile and spine. The vesicles are usually lower in number than those of the Type A terminal.

3) Type $C$, this type of terminal is also of small size and filled with pleomorphic vesicles, which are uniformly distributed within the terminal. A few mitochondria are usually present in this type of terminal. Synaptic junctions made by this type of terminal are symmetrical (Fig. 15). 
4) Type $\mathrm{D}$ is a large $(2-3 \mu)$ terminal filled with numerous, uniformly distributed pleomorphic vesicles, and contains many mitochondria and a number of glycogen-like granules in addition (Fig. 14). This type forms symmetrical synaptic contact with the dendrite.

5) Type E terminal, forming asymmetrical synaptic contact with the dendrite, contains many granular vesicles $(800-1,000 \AA)$ and is found only infrequently in the claustrum (Fig. 16).

These types of axon terminals make synapses of various forms with the claustral neurons.

Axo-somatic synapse; synaptic contacts of this sort are few on the Class I, II and III neurons ( $0-5 /$ neuronal profile) but the Class IV (large neuron) is covered with many (25 or more/profile) terminals of various types (Fig. 6).

Axo-dendritic synapse; though very restricted in number, the dendritic profiles with many mitochondria, ribosomes and endoplasmic reticulum in them receive many synaptic terminals (mostly Type A). Some of these types of dendritic profiles are found to be from the Class IV neurons (Fig. 11a, b). Most of the dendritic profiles have a few mitochondria, ribosomes and endoplasmic reticulum in them and, on a few occasions, these dendrites and spines from them, if present, are seen making synaptic contacts with axon terminals (mostly Type $\mathrm{C}$ and $\mathrm{A}$, respectively). The dendrites from the Class I, II and III neurons mainly take the latter type of the dendritic profiles (Fig. 12a, b).
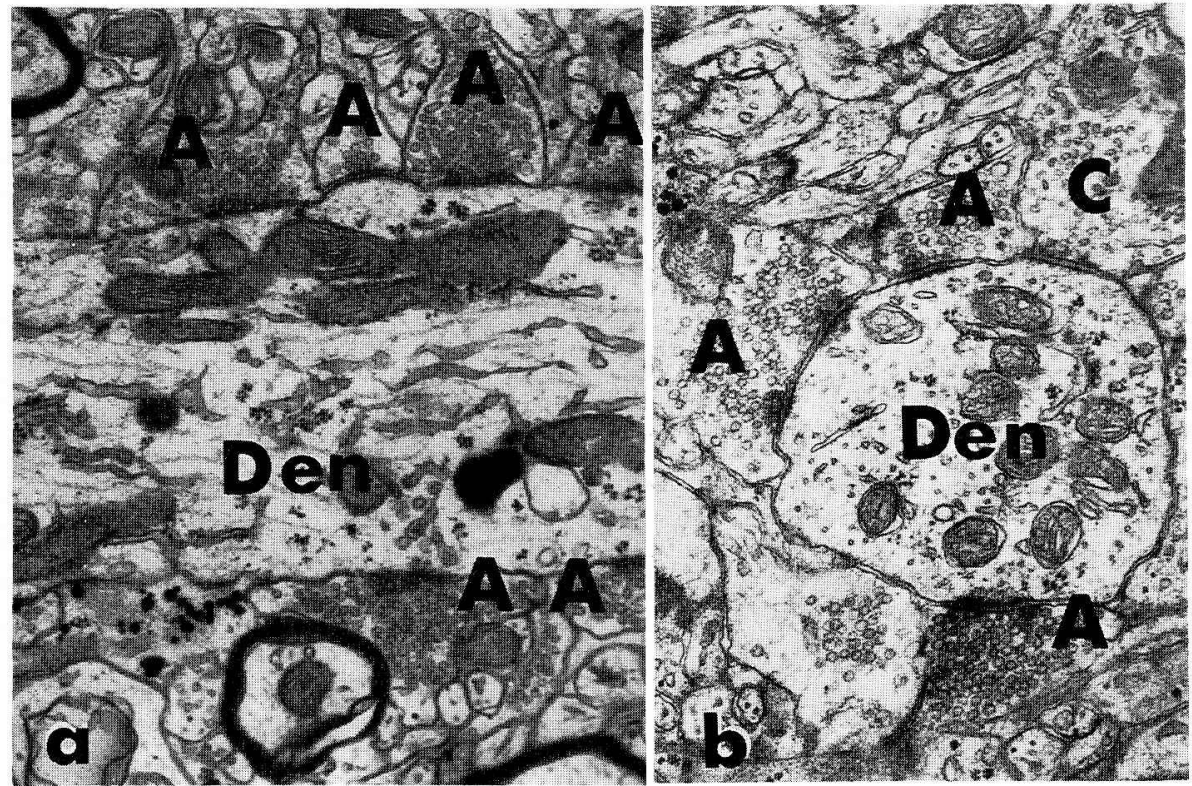

Fig. 11. The dendritic profiles of Class IV neurons. a. A dendrite (Den) of Class IV neuron receives synaptic contacts of many axon terminals $(A)$ containing round vesicles. $\times 20,000$ b. This type of dendrite (Den) contains many mitochondria and other dendritic organelles, and is covered with several axon terminals. Two types of synapses are present; one of them is of Type $\mathrm{A}(A)$ and other is of Type $\mathrm{C}(C) . \quad \times 30,000$ 


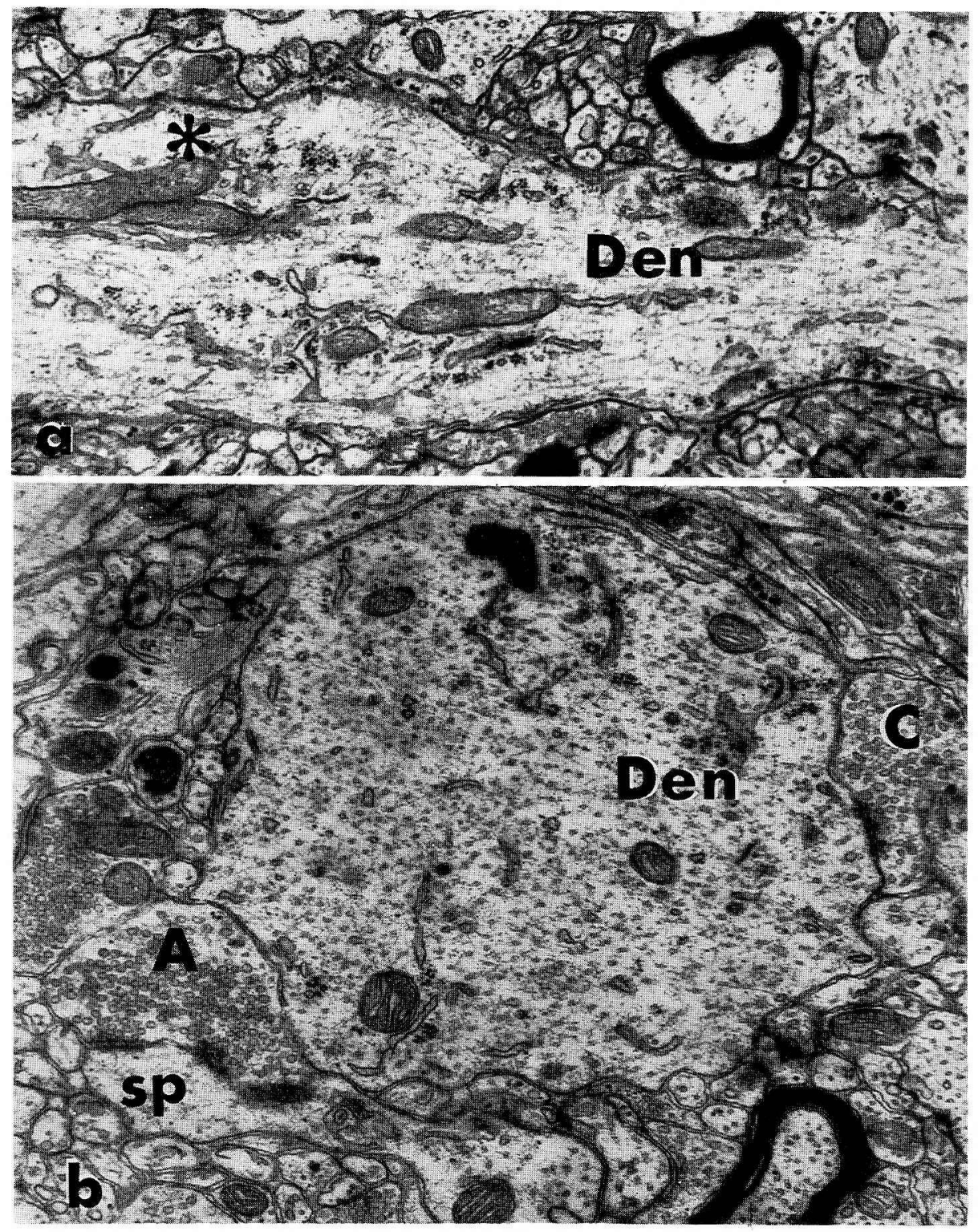

Fig. 12. a. The proximal dendrite (Den) of Class II neuron possessing the organelles which are found in the cytoplasm as well. An axon terminal which contains the pleomorphic vesicles synapses upon this dendrite (asterisk). $\times 20,000$ b. A proximal dendrite (Den) from a neuron other than Class IV is cross sectioned. This type of dendrite contains a few mitochondria and numerous microtubules and bears a few axon terminals $(C)$. A dendritic spine $(s p)$ synapsing with a Type A terminal $(A)$ is also indicated. $\times 30,000$ 


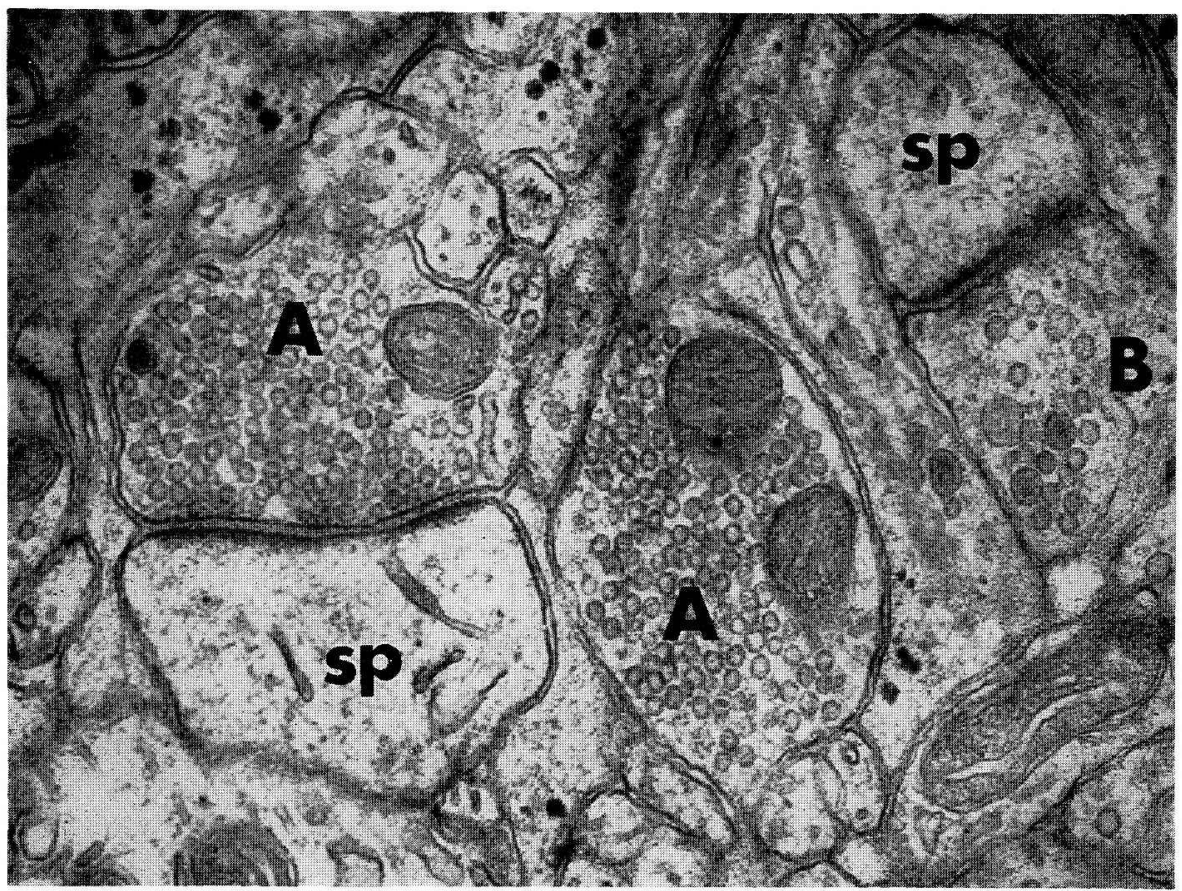

Fig. 13. Two types of axon terminals in the claustral neuropile. Type A terminal $(A)$ with uniform sized round vesicles making asymmetrical synapse with a dendritic spine $(s p)$. Type $\mathrm{B}(B)$ containing round vesicles of various diameters and synapses upon a dendritic spine. $\times 50,000$

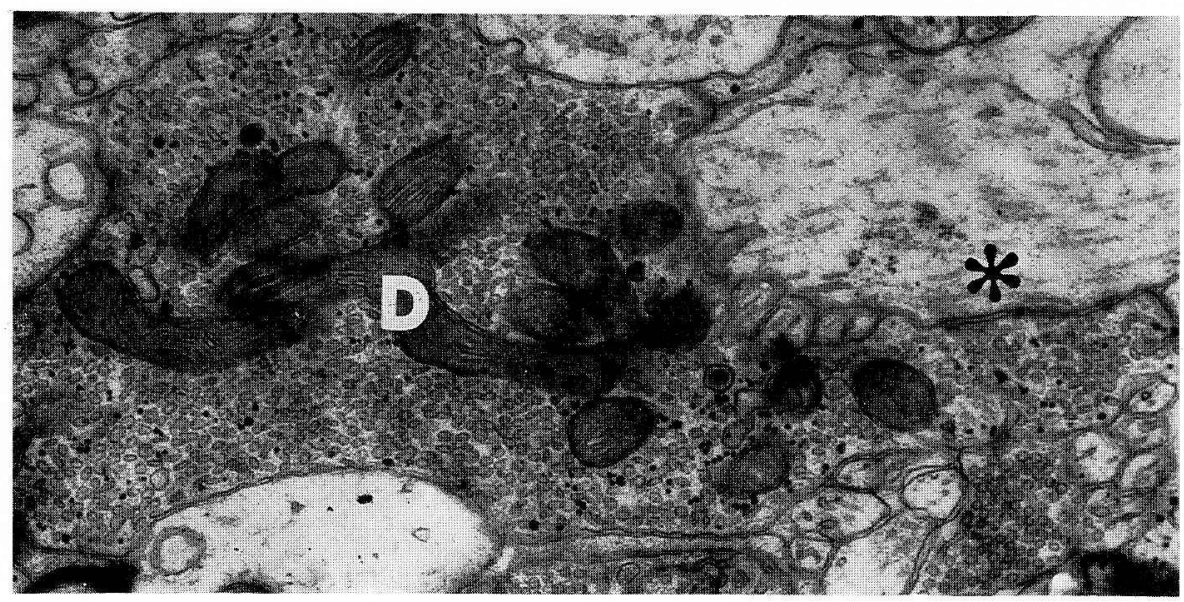

Fig. 14. Type D terminal $(D)$. This type of terminal contains numerous pleomorphic vesicles, many mitochondria and a number of glycogen-like granules. Note the symmetrical synaptic contact with the dendrite (asterisk). $\quad \times 30,000$ 
Axo-axonal synapse; in the claustrum, axo-axonal synapses are found only between the initial segment of axons and Type $C$ terminals (Fig. 9, 10).

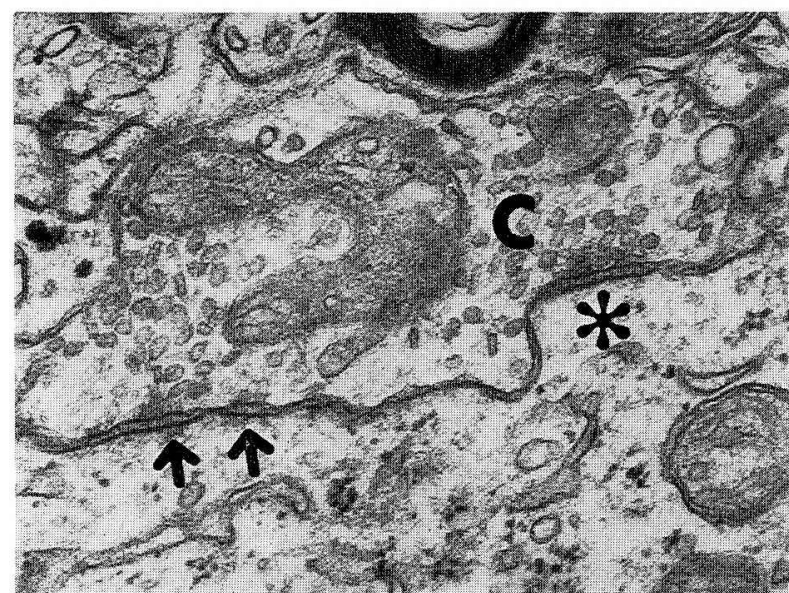

Fig. 15. Type $\mathrm{C}$ terminal $(C)$, containing pleomorphic vesicles and making symmetrical synapse with the surface of the claustral neuron somata (asterisk). Arrows indicate punctae adhaerentiae. $\times 50,000$

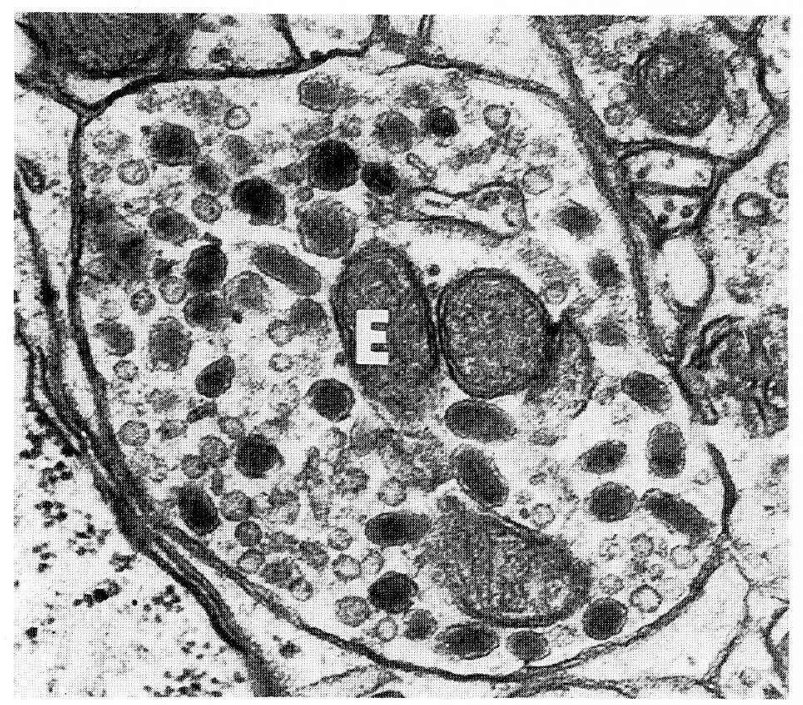

Fig. 16. Type $\mathrm{E}(E)$ terminal containing round vesicles of various diameters and many granular vesicles. $\times 50,000$

\section{Discussion}

The present light and electron microscopical observations suggest that the claustrum is a complex structure in which different classes of neurons and various kinds of terminals are present. The claustral neurons can be divided into four classes by their shape, size, localization, and cytological characteristics, and the findings at the light microscope level are easily identifiable at the ultrastructural level, too. Although there are various shapes of the mediumsized neurons in this nucleus, the cytology of these neurons is quite similar, making it possible for those neurons to be classified collectively into the category of the medium neuron. Except for the peripheral and intermediate areas of the claustrum in which the fusiform neurons are predominant, the medium neurons occupy the major part of all claustral neurons. These medium neurons may correspond mostly to the large multipolar, large pyramidal and round cells of Druga (1966a). The large neurons are so conspicuous that they are easily recognized, and they are covered by many axonal boutons, in con-

trast to other claustral neurons with a few axonal boutons on them. The differences in these synaptic arrangements between the large (Class IV) and other claustral neurons suggest that the functions of the former may differ from the latter. The fusiform neurons, which may correspond to the fusiform and ovoid cells of RAE (1954) or spindle cells of DRUGA (1966a), have remarkable similarities in their cytology to the 
medium neurons. As the localization of fusiform neurons, however, is quite different from the medium one, it seems reasonable to consider that their functions may also differ. The small neurons, which are dispersed throughout the claustrum, are also easily recognized by their small size and relatively dense nucleus. In our Golgi obseryations (unpublished) they are considered as Golgi type II neurons whose axons have numerous ramifications confined within the claustrum.

According to the previous studies, at least some of the axonal endings in the claustrum have been considered to originate from the following structures: the cerebral cortex (CARMan, Cowan and Powell, 1964; Narkiewicz, 1964, 1966; Druga, 1966b, 1968, 1971; Juraniec, Narkiewicz and Wrzolkowa, 1971), the amygdaloid complex (Gurdjian, 1928; Naut A, 1961), the thalamus (Naut A and Whitlock, 1954), the nucleus locus caeruleus (Pickel, Segal and Bloom, 1974), and the striatum and substantia nigra (ANDERSEN, 1968). Moreover, intrinsic axonal endings are also present (our unpublished Golgi data).

According to Juraniec, NARKIEwICZ and WrzoŁKow (1971), cortico-claustral connections are mostly axo-dendritic and of the asymmetrical type, which occurs usually on the small dendritic branch and spine, and probably corresponds to our Type A terminal. The present study, however, shows that, although axon terminals synapsing upon small dendritic branches and spines are mostly of Type A, a few Type B, C and $\mathrm{D}$ are also present. Therefore these three (Type B, C and D) kinds of axon terminals might represent inputs from brain regions other than the cerebral cortex. At present, the problem of the brain regions which give rise to these types of terminals waits further elucidation.

The presence of the axon terminals containing numerous granular vesicles (Type E) may represent the catecholaminergic projections from the locus caeruleus suggested by Pickel, Segal and Bloom (1974).

\section{ネコ前障の電子顕微 鏡による観察}

$$
\text { 車田正男と平田幸男 }
$$

正常ネコ前障を構成している神経細胞は 電子顕微鏡によって 4 種類 ( I - $N$ 型) に分類 できる. IV 型のノイロンは 核周部ないし樹状突起が多くの終末により お抒われているが, 他のノイロンには極めて少数の終末しか認められない.

前障にみられる終末はその形態から5つのタイプに分類できる. タイプ A は丸い均一な 径のシナプス小胞を含み, 非対称性膜肥厚を呈するシナプス結合を作る小型の終末である. タイプ B はシナプス小胞の大きさにばらつきがみられるほかは，タイプ Aとほぼ同様な形 態它示す．多形性シナプス小胞を有する小型のタイプCと, 多形性シナプス小胞, 多くの ミトコンドリア，グリコゲン様顆粒を有している大型のタイプDは，ともに対称性シナプ

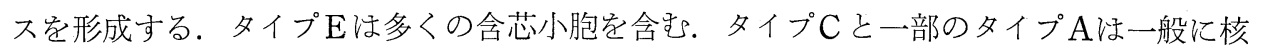
周部や近位樹状突起にシナプス军つくるが，他のものほ比較的細い樹状突起と，樹状突起 の棘に終る. 
電子顕微鏡で分類できる神経細胞が 光学顕微鏡によるそれとそれぞれ一致するかどう か,さらに数種の終末の由来はどこか,なぞについて検討した.

\section{References}

Andersen, D. L.: Some striatal connections to the claustrum. Exp. Neurol. 20: 261-267 (1968). Ariëns Kappers, C. U., G. C. Huber and E. C. Crosby : Comparative anatomy of the nervous system of vertebrates, including man. 2 vols, New York, Macmillan Co., 1936.

Brockhaus, H. : Zur normalen und pathologischen Anatomie des Mandelkerngebietes. J. Psychol. Neurol. 49: 1-136 (1938).

-: Die Cyto- und Myeloarchitektonik des Cortex claustralis und des Claustrum beim Menschen. J. Psychol. Neurol. 49: 250-348 (1940).

Carman, J. B., W. M. Cowan and T. P. S. Powell : The cortical projection upon the claustrum. J. Neurol. Neurosurg. Psychiat. 27: 46-51 (1964).

Colonnier, M. : Synaptic patterns on different cell types in the different laminae of the cat visual cortex. An electron microscope study. Brain Res. 9: 268-287 (1968).

Druga, R.: The claustrum of the cat (Felis domestica). Fol. morphol. (Praha). 14: 7-16 (1966a). - Cortico-claustral connections. I. Fronto-claustral connections. Fol. morphol. (Praha). 14: 391-399 (1966b).

- Cortico-claustral connections. II. Connections from the parietal, temporal and occipital cortex to the claustrum. Fol. morphol. (Praha). 16: 142-149 (1968).

-: Projection of prepyriform cortex into claustrum. Fol. morphol. (Praha). 19: 405-410 (1971).

-: Efferent projections from the claustrum (an experimental study using Nauta's method). Fol. morphol. (Praha). 20: 163-165 (1972).

-: The claustrum and the transitional neo-paleocortical area of the hedgehog (Erinaceus europaeus). Anat. Anz. 135: 442-454 (1974).

Filimonoff, I. N.: The claustrum, its origin and development. J. Hirnforsch. 8: 503-528 (1966).

Gurdjian, E. S.: The corpus striatum of the rat. J. comp. Neurol. 45: 249-281 (1928).

Juraniec, J., O. Narkiewicz and T. Wrzolkowa : Axon terminals in the claustrum of the cat: an electron microscope study. Brain Res. 35: 277-282 (1971).

Karlsson, U. and R. L. Schultz : Fixation of the central nervous system for electron microscopy by aldehyde perfusion. J. Ultrastr. Res. 12: 160-186 (1965).

Kishi, K.: Two types of cytoplasmic nucleolus-like bodies. Observation of the serial sections of rat neurons. Arch. histol. jap. 35: 83-87 (1972).

Le Beux, Y. J.: An ultrastructural study of the neurosecretory cells of the medial vascular prechiasmatic gland, the preoptic recess and the anterior part of the suprachiasmatic area. I. Cytoplasmic inclusions resembling nucleoli. Z. Zellforsch. 114: 404-440 (1971).

Luft, J. H.: Improvements in epoxy resin embedding methods. J. biophys. biochem. Cytol. 9: 409-414 (1961).

Miodoński, R.: The claustrum in the dog brain. Acta anat. 91: 409-422 (1975).

Narkiewicz, 0.: Degenerations in the claustrum after regional neocortical ablations in the cat. J. comp. Neurol. 123: 335-356 (1964).

- Connections of the claustrum with the cerebral cortex. Fol. morphol. (Warszawa) 25: 517-523 (1966).

Nauta, W. J. H.: Fiber degeneration following lesions of the amygdaloid complex in the monkey. J. Anat. 95: 515-531 (1961).

Nauta, W. J. H. and D. G. Whitlock: An anatomical analysis of the non-specific thalamic 
projection system. In: (ed. by) J. F. Delafresnaye: Brain mechanisms and consciousness. Oxford, Oxford University Press, 1954. (p. 81-116).

Palay, S. L.: The morphology of synapses in the central nervous system. Exp. Cell Res. Suppl. 5: 275-293 (1958).

Palay, S. L., C. Sotelo, A. Peters and P. M. Orkand: The axon hillock and the initial segment. J. Cell Biol. 38: 193-201 (1968).

Peters, A. and S. L. Palay : The morphology of laminae A and $A_{1}$ of the dorsal nucleus of the lateral geniculate body of the cat. J. Anat. 100: 451-486 (1966).

Peters, A., S. L. Palay and H. de F. Webster: The fine structure of the nervous system. The cells and their processes. New York, Hoeber/Harper and Row, 1970.

Pickel, V. M., M. Segal and F. E. Bloom : A radioautographic study of the efferent pathways of the nucleus locus coeruleus. J. comp. Neurol. 155: 15-42 (1974).

Rae, A. S. L.: The form and structure of the human claustrum. J. comp. Neurol. 100: 15-39 (1954).

Rose, M. : Die Ontogenie der Inselrinde. Zugleich ein Beitrag zur histogenetischen Rindeneinteilung. J. Psychol. Neurol. 36: 182-209 (1928).

Spector, I. : Functional organization of the claustrum. Anat. Rec. 163: 269 (1969).

Spector, I., Y. Hassmannova and D. Albe-Fessard : A macrophysiological study of functional organization of the claustrum. Exp. Neurol. 29: 31-51 (1971). Res. 66: 39-65 (1974).

Venable, J. H. and R. Coggeshall : A simplified lead citrate stain for use in electron microscopy. J. Cell Biol. 25: 407-408 (1965).

Vries, E. de: Bemerkungen zur Ontogenie und Phylogenie des Claustrums. Fol. neurobiol. 4: 481-513 (1910).

Westrum, L. E. : Observations on initial segments of axons in the prepyriform cortex of the rat. J. comp. Neurol. 139: 337-356 (1970).

Whitaker, J. R.: Anatomy of the brain and spinal cord. 5th ed., Edinburgh, E. S. Livingston, 1921.

車田正男

于951 新潟市旭町通 1

新潟大学医学部

解剖学第二教室
Dr. Masao NoRita

Department of Anatomy

Niigata University School of Medicine

Niigata, 951 Japan 